\title{
Mechanisms in mutualisms: a chemically mediated thrips pollination strategy in common elder
}

\author{
Alison S. Scott-Brown ${ }^{1}$ (1) - Sarah E. J. Arnold ${ }^{2}$. Geoffrey C. Kite ${ }^{1}$ lain W. Farrell ${ }^{1}$. Dudley I. Farman ${ }^{2}$. \\ Dominique W. Collins ${ }^{3} \cdot$ Philip C. Stevenson ${ }^{1,2}$
}

Received: 23 January 2019 / Accepted: 26 April 2019 / Published online: 8 May 2019

(c) The Author(s) 2019

\begin{abstract}
Main conclusion This study provides first evidence of a thrips species pollinating Sambucus nigra and describes how interactions are driven by plant biochemical signalling and moderated by temporal changes in floral chemistry.
\end{abstract}

\begin{abstract}
The concept of flower-feeding thrips as pollinating insects in temperate regions is rarely considered as they are more frequently regarded to be destructive florivores feeding on pollen and surrounding plant tissue. Combining laboratory and field-based studies we examined interactions between Sambucus nigra (elderflower) and Thrips major within their native range to ascertain the role of thrips in the pollination of this species and to determine if floral chemicals mediated flower visits. If thrips provide a pollination service to $S$. nigra, then this will likely manifest in traits that attract the pollinating taxa at temporally critical points in floral development. T. major were highly abundant in inflorescences of $S$. nigra, entering flowers when stigmas were pollen-receptive and anthers were immature. When thrips were excluded from the inflorescences, fruit-set failed. Linalool was the major component of the inflorescence headspace with peak abundance coinciding with the highest number of adult thrips visiting flowers. Thrips were absent in buds and their numbers declined again in senescing flowers inversely correlating with the concentration of cyanogenic glycosides recorded in the floral tissue. Our data show that S. nigra floral chemistry mediates the behaviour of pollen-feeding thrips by attracting adults in high numbers to the flowers at pre-anthesis stage, while producing deterrent compounds prior to fruit development. Taking an integrative approach to studying thrips behaviour and floral biology we provide a new insight into the previously ambiguously defined pollination strategies of S. nigra and provide evidence suggesting that the relationship between T. major and S. nigra is mutualistic.
\end{abstract}

Keywords Cyanogenic glycosides $\cdot$ Elderflower $\cdot$ Floral chemistry $\cdot$ Floral traits $\cdot$ Non-bee pollinator $\cdot$ Prunasin $\cdot$ Sambucus nigra $\cdot$ Sambunigrin $\cdot$ Thysanoptera $\cdot$ Volatile organic compounds

\section{Abbreviation \\ CNglcs Cyanogenic glycosides}

Electronic supplementary material The online version of this article (https://doi.org/10.1007/s00425-019-03176-5) contains supplementary material, which is available to authorized users.

Alison S. Scott-Brown

a.scott-brown@kew.org

Royal Botanic Gardens Kew, Richmond TW9 3AB, UK

2 Natural Resources Institute, University of Greenwich, Chatham Maritime ME4 4TB, UK

3 The Hunterian, University of Glasgow, Glasgow G3 8AW, UK

\section{Introduction}

Mutualisms between insects and plants drive functional-trait diversification in plants (Boucher et al. 1982; Bronstein et al. 2006). Floral traits mapped against pollinator data and pollination syndromes have informed the debate (Johnson and Steiner 2000; Ollerton et al. 2007; Mitchell et al. 2009), although generalist systems where plants are pollinated by many insect species, or by wind (Waser et al. 1996; Wragg and Johnson 2011; Yamasaki and Sakai 2013), are harder to define. Furthermore, pollinator efficiency (Gross 2005; Waser and Ollerton 2006), size and cryptic behaviour may obscure associations between floral traits and specific insect visitors capable of increasing pollination success (Vogel 1978). 
Flowers provide many thrips (Thysanoptera) with a food source and a site for reproduction (Teulon and Penman 1990) and in return thrips can contribute to the pollination of these species (e.g., Velayudhan and Annadurai 1987; Ashton et al. 1988; Mound and Terry 2001; Moog et al. 2002; Infante et al. 2017). The capacity of thrips to transfer pollen withinspecies (Darwin 1876; Ananthakrishnan 1984; Proctor et al. 1996) and their flight agility (Kirk 1997) support growing evidence that they are brood-site pollinators (Sakai 2002), effective in transferring pollen of species that possess adaptations associated with wind pollination, such as many flowers, abundant powdery pollen and large stigmas (Tal 2009).

Most thrips pollination systems recorded are tropical and sub-tropical, with only a few studies in temperate species (Hagerup and Hagerup 1953; Tal 2009; Fukuhara and Tokumaru 2014). While the pollination ecology of Sambucus spp. (Adoxaceae) remains poorly understood (Grime et al. 1988; Bolli 1994; Charlebois et al. 2010) the floral morphology of European Elder, Sambucus nigra L., corresponds with a thrips pollination syndrome (Kirk 1988; Endress 1994; Williams and Adam 1994). Several authors have observed Thrips spp. present in flowers of S. nigra (Morison 1968; Mound et al. 1976; Raspudić et al. 2009), most notably Ward (1973) recorded S. nigra as a breeding host of the polyphagous species Thrips major Uzel (Thripidae) during a survey of native thrips species in flowers of a chalk grassland in southern England.

Here we examine whether thrips pollinate $S$. nigra and if floral chemistry mediates thrips-elder interactions. Our objectives were to (i) examine if thrips in flowers contribute to fruit-set, (ii) determine if floral volatiles fluctuate over $24 \mathrm{~h}$ and during flower development and if emission of key scent constituents correlates with thrips numbers foraging in flowers, (iii) identify and map the temporal distribution of cyanogenic glycosides (CNglcs) in floral tissue as flowers develop in relation to numbers and life stages of thrips present in flowers. Further laboratory assays were performed to test the volatile complexes and isolated $\mathrm{CNglcs}$ on the behaviour of thrips, thus examining the hypothesis that floral chemical traits of $S$. nigra are attracting and influencing the duration of visitation of native pollen-feeding thrips and potentially benefiting from a pollination service provided by these insects.

\section{Materials and methods}

\section{Flower morphology of study species}

The small, hermaphrodite flowers of Sambucus nigra L. are white, highly scented and arranged in inflorescences of up to 1000 pedicellate flowers (Bolli 1994). Flowers of this species are protogynous (Knuth 1906) and lack floral nectaries, although extrafloral nectaries are present at the base of leaves and leaflets (Dammer 1890; Atkinson and Atkinson 2002). Development stages of the flowers are shown in Fig. 1a-d.

\section{Thrips sampling}

Sampling of S. nigra inflorescences and thrips was undertaken in May and June (2016), from bud-break to fruit development, from ten plants 200-400 m apart, bordering open pasture on a conventional lowland dairy farm (Henfield, West Sussex, UK). Sampling occurred between 08:00 and 10:00, except where diurnal foraging activity was assessed, when collections were repeated at 06:00, 12:00, and 18:00. For each collection one inflorescence per plant was cut and submerged into $100 \mathrm{~mL}$ of $80 \%$ ethanol and stored $\left(4^{\circ} \mathrm{C}\right)$. After $24 \mathrm{~h}$ plant material was discarded and the immature and adult thrips counted under a Leica M165 FC light microscope (Leica Microsystems Ltd., Milton Keynes, UK). From these, 36 adults (16 females, 20 males) were removed from a sub-set of 221 examined closely to exclude species variability, slide mounted, examined under high-power magnification (x100-x400) and identified to species by reference to published keys (e.g., Mound et al. 2018). Similarly, 20 second-instar larvae were slide-mounted (subsample of 477) and characterised (Vierbergen et al. 2010).

\section{Insect exclusion}

Pollinator exclusion bags were constructed from two sheets $(20 \mathrm{~cm} \times 20 \mathrm{~cm})$ of nylon mesh machine-stitched together with a central aperture enabling the bag to be placed over a developing inflorescence in bud ( $<1 \mathrm{~cm}$ diam.) and secured by hand-stitching closely around stem. Fifteen inflorescences were selected on each of ten trees. To determine the contributions of thrips to fruit-set, three levels of vector exclusion were used: (1) open to all insect- and wind-transmitted (cross and self) pollen; (2) mesh aperture $1 \mathrm{~mm}$ diam. to prevent insects larger than T. major (1 mm) from access and (3) mesh aperture $0.125 \mathrm{~mm}$ diam. to exclude thrips but large enough to allow pollen through (average diam. 13-18 $\mu \mathrm{m}$, Bolli 1994) ( $n=5$ per treatment). After 6 weeks the number of developing fruits was recorded. Pollination resulting from pollen transfer between flowers within inflorescence due to a combination of wind (cross) and mechanical disturbance (self) was determined by comparing (1) and (3), where open inflorescences (1) facilitated $100 \%$ pollination. Thrips pollination was determined comparing (2) with (3) - (1). Forficula auricularia L. (Dermaptera: Forficulidae) destroyed several inflorescences and these were not included in the final analyses. 
Fig. 1 Five key flower development stages (DS) in S. nigra, observed during the flowering period in 2016. a Unopened buds on inflorescence (DS0). $\mathbf{b}$ Flowers open on inflorescence, pre-anthesis stage with visible lobed stigma (Donoghue et al. 2003): (DS1 $\leq 50 \%$ flowers of inflorescence open, DS2 $\geq 90 \%$ ). c Flowers at anthesis with divergent stamens (DS3). Adult female T. major feeding on pollen. d Flowers post-anthesis stage (DS4). Adult male $T$. major in flower
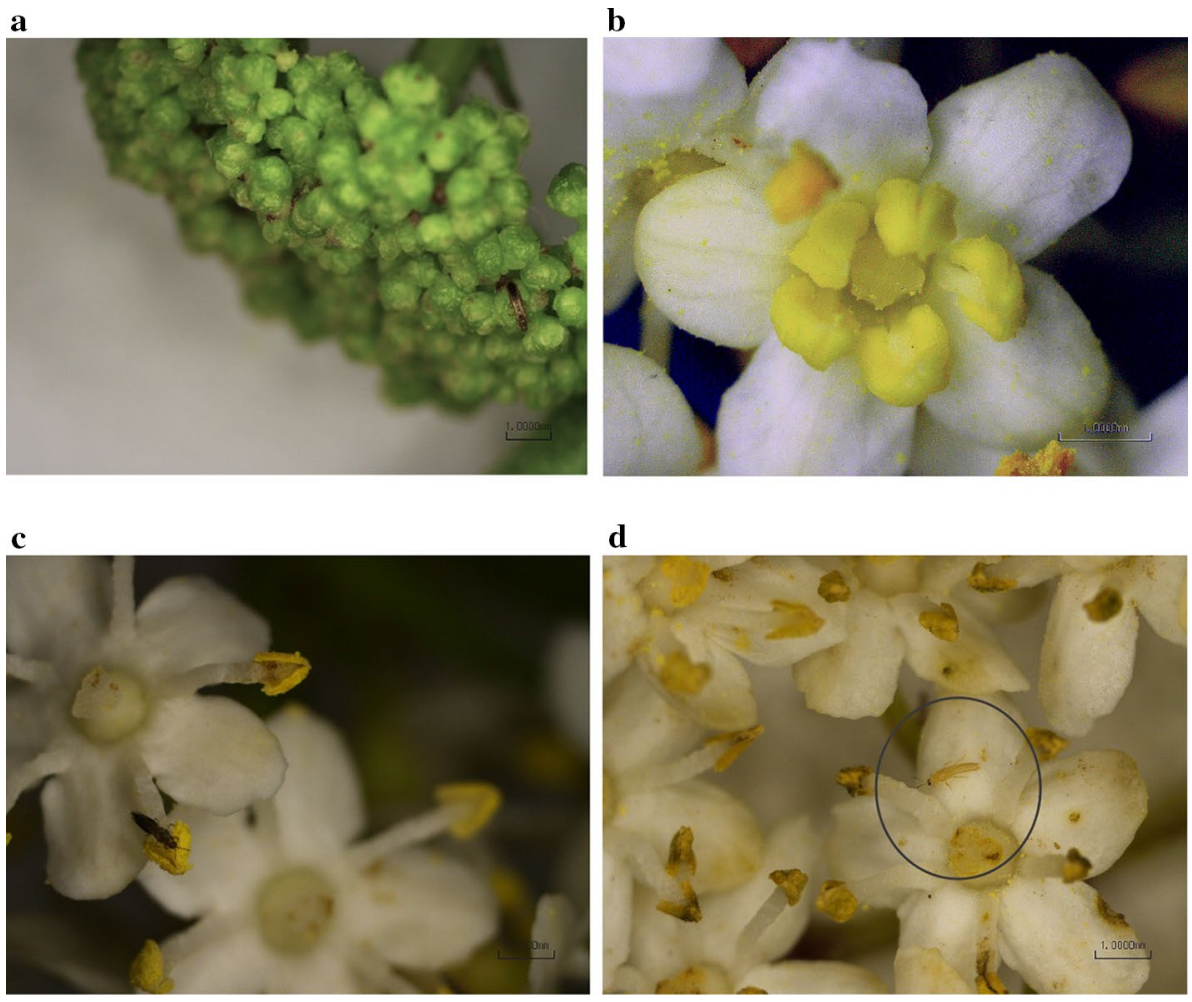

\section{Chemical analysis of S. nigra flowers and insect bioassays}

\section{Volatile organic compound (VOC) emissions during floral development}

VOCs were collected in situ from inflorescences to identify main constituents of floral emissions. For the headspace sampling we selected inflorescences with unopened buds (Fig. 1; DS0), up to 50\% flowers open (DS1), >90\% open (DS2 and DS3) and senescing flowers (DS4) and used leaf material as the background control. A clear oven bag $(280 \times 300 \mathrm{~mm}$, Sainsbury's Ltd., London, UK) was placed over floral tissue and tied securely with wire fasteners around the stem. Air flow $\left(100 \mathrm{~cm}^{3} \mathrm{~min}^{-1}\right)$ was introduced via air-in, through a filter of activated charcoal $(20 \times 2 \mathrm{~cm} ; 10-18$ mesh, Fisher Chemicals), and air-out silicon tubing, inflating the bag around the inflorescence (air pump system, Barry Pye, Harpenden, UK). A glass pipette $(150 \mathrm{~mm})$ packed with Porapak-Q resin $(200 \mathrm{mg}$, 50/80 mesh; Waters Corporation) held between plugs of silanized glass wool was inserted into the air-out tubing, ensuring that air leaving the sampling bag was forced out through the pipette and resin first before entering the airout tubing. Each collection occurred over $24 \mathrm{~h}(10-10 \mathrm{am})$ after which the pipettes were removed, sealed in foil and returned to laboratory for analysis. During a $24 \mathrm{~h}$ sampling period flower development progressed to the next development stage so for analysis DS0 and DS1 data and DS2 and DS3 data were combined to compare VOC emissions from inflorescences predominantly in bud against inflorescences containing young flower stages, inflorescences with senescing flowers (DS4) and vegetative material only.

\section{Circadian abundance of VOCs}

VOCs from inflorescences (DS2) were analysed over four time periods, each for a duration of $6 \mathrm{~h}$ (12:00-18:00, 18:00-00:00, 00:00-06:00, 06:00-12:00).

Resin-captured VOCs were eluted with $1000 \mu \mathrm{L}$ dichloromethane (99.5\% chromatographically pure). Samples were analysed using a Varian 3800 gas chromatograph (GC) equipped with DB-Wax column (30 $\mathrm{m}$ long, $0.25 \mathrm{~mm}$ inner diameter, $0.25 \mathrm{~mm}$ film thickness), and linked to a Varian Saturn 2200 mass spectrometer (MS). Helium was used as a carrier gas at a flow rate of $1 \mathrm{~mL} \mathrm{~min}{ }^{-1}$. Column temperature was programmed to rise from $40{ }^{\circ} \mathrm{C}$ ( 5 min hold $)$ to $250{ }^{\circ} \mathrm{C}$ (20 min hold) at $3{ }^{\circ} \mathrm{C} \mathrm{min}^{-1}$. The mass spectra were recorded at $70 \mathrm{eV}$ (in EI mode) with speed of one scan s${ }^{-1}$, from 40 to $400 \mathrm{~m} / \mathrm{z}$. Compounds were identified by comparing mass spectra and relative retention times with standard compounds (Sigma-Aldrich) and with the NIST 05 mass spectral library. Proportional abundance of component VOCs in total scent emissions were compared (total ion mode) using peak area measurements to identify any 
variation in representation in floral development stages or circadian rhythm emissions.

\section{Olfactory tests with floral VOCs}

Adult female T. major were collected from wild populations on S. nigra inflorescences. Individuals were deprived of food prior to experiments for $1 \mathrm{~h}$ and used in a single trial only.

Y-tube olfactometer experiments were conducted between 9:00 and $16: 00$ at $25{ }^{\circ} \mathrm{C}$ and ambient humidity. A pump (FB65540, Fisher Scientific) drew air through a charcoal filter to remove volatile contaminants, then air was split and passed down silicone tubing to two gas-wash bottles, one containing the test stimuli (VOCs eluents from Porapak$\mathrm{Q}$ filters suspended in dichloromethane, 50\% dilution, see Suppl. Fig. S1) and the other the solvent control (100\% dichloromethane) and then into each of the two arms of the glass Y-tube olfactometer at a rate of $100 \mathrm{~cm}^{3} \mathrm{~min}^{-1}$. Odour stimuli were replaced and stimuli and control bottle positions switched after every fifth trial. The Y-tube apparatus was regularly flushed through with industrial methylated spirits (IMS) and allowed to air-dry to remove odour cues from previous thrips.

Individual insects were introduced into the approach arm of the olfactometer. A decision was recorded when an insect entered one or the other arm of the olfactometer and the decision time was recorded. Decisions taken after 3 min were excluded from analysis.

\section{Florivore defence}

\section{CNglcs and floral development}

Buds, flowers and fruit were collected from ten $S$. nigra individuals and stored at $-20{ }^{\circ} \mathrm{C}$. Extracts were made by boiling $100 \mathrm{mg}$ of finely ground freeze-dried plant material

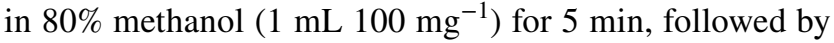
rapid cooling on ice. Extracts were centrifuged $(11,000 g$; $5 \mathrm{~min}$ ) and the supernatant analysed directly by LC-MS using an LTQ Orbitrap XL system (Thermo Scientific). Chromatography was performed with a $150 \mathrm{~mm} \times 3 \mathrm{~mm}$ (i.d.), $3 \mu \mathrm{m}$, Luna C18(2) column (Phenomenex) using a $400 \mu \mathrm{L} \mathrm{min}{ }^{-1}$ mobile-phase gradient mixed from $\mathrm{H}_{2} \mathrm{O} /$ $\mathrm{MeOH} / \mathrm{CH}_{3} \mathrm{CN}+1 \% \mathrm{HCOOH}$ of 90:0:10-50:40:10 (by vol.) in $20 \mathrm{~min}$. Concentrated aqueous ammonia was infused post column at $0.1 \mu \mathrm{L} \mathrm{min}{ }^{-1}$ to augment ionisation. Quantification was performed on the ammoniated molecule at $\mathrm{m} / \mathrm{z} 313.1394( \pm 5 \mathrm{ppm})$ extracted from a positive ion MS1 scan of $\mathrm{m} / \mathrm{z}, 125-600$ at $30 \mathrm{k}$ resolution; low-resolution ion trap MS2 data on $m / z, 313$ were acquired simultaneously for confirmation. Standard curves were obtained from prunasin (Sigma-Aldrich) and sambunigrin (Toronto Research
Chemicals Inc.) which eluted at $10.1 \mathrm{~min}$ and $10.6 \mathrm{~min}$, respectively, under the conditions used.

\section{Effect of CNglcs on feeding preference}

Choice tests were set up to assess if extracts of bud (DS0), flower (DS3) and green fruit (DS5) tissue of S. nigra influenced thrips behaviour compared to leaf tissue. Fresh tissue was ground with $70 \%$ ethanol $\left(20 \mathrm{mg} \mathrm{mL}^{-1}\right)$, filtered and freeze-dried, prior to applying as treatments in bioassays at $100 \mathrm{mg} \mathrm{mL}^{-1}$. Pure prunasin and sambunigrin were diluted in distilled water to $0.1,1.0,10,100 \mathrm{mg} \mathrm{mL}^{-1}$ and each treatment applied $(100 \mu \mathrm{L})$ as a residue to $500 \mathrm{mg}$ of excised S. nigra flowers and air dried for $20 \mathrm{~min}$. Distilled water $(100 \mu \mathrm{L})$ only was applied to flowers for the control. Treated and untreated flowers were positioned on opposite sides of compartmentalised Petri-dishes $(9 \mathrm{~cm})$ on moistened filter paper (200 $\mu \mathrm{L}$ distilled water). An adult female thrips (collected from wild $S$. nigra source, food deprived $1 \mathrm{~h}$ ) were placed centrally in Petri-dish and lid sealed in place with parafilm (reduced light, ambient temperature $25^{\circ} \mathrm{C}$ ). Thrips foraging among treated or control flowers were recorded after $6 \mathrm{~h}$. Thrips on sides of Petri-dishes were excluded from selection preference data.

\section{Statistical analysis}

The distribution of thrips' life stages in inflorescences was examined spatially (floral development) using analysis of variance transformation (ANOVA, $\log +1$ ) to determine overall differences (median \pm interquartile range), and in all analysis included a post hoc Tukey's multiple comparison test (Tukey HSD) to identify differences (R Core Team 2016). Similarly, thrips exclusion experiments were examined with ANOVA $\log$ (thrips+1) followed by Tukey HSD to identify differences between treatments. Abundance and temporal variation of VOCs were compared using ANOVA without transformation, and with Tukey HSD test to indicate where differences lay. A binomial test was performed for each odour stimulus, additionally applying the Bonferroni correction adjustment to account for multiple comparisons (SPSS Version 23, IBM Corperation). CNglc concentrations were analysed using Kruskal-Wallis one-way analysis of variance $(\mathrm{KW})$ applying Shapiro-Wilk test first to check distribution range, applying binomial tests for dual-choice tests using $95 \%$ confidence interval for differences between choice-selection (treatment or control) proportions GENSTAT 14.2 (VSN International Ltd.). 


\section{Results}

\section{Thrips sampling}

A total of 7450 thrips were collected from 127 inflorescences from ten $S$. nigra individuals during flowering. All slide-mounted adults and larvae were T. major. This was frequently the only insect species present with occasional pollen beetles (Nitidulidae: Meligethes spp.), a single individual of Frankliniella intonsa (Trybom) (Thripidae) and a few facultative predatory species Aeolothrips intermedius Bagnall (Aeolothripidae). Observation under a microscope revealed that adult and immature thrips moved rapidly over and between stamens and gynoecia with multiple pollen grains adhered to the wings and abdominal setae of adult male and female T. major in flowers at anthesis stage (Suppl. Fig. S2).

Thrips were absent from S. nigra inflorescences in bud (DS0; Figs. 2 and 3). Overall, flower stage influenced thrips numbers in inflorescences (Fig. 2: ANOVA, $F=70.5$, $P<0.0001)$ although there was no difference between the sex ratio (ANOVA, $F=0.17, P>0.05$ ). Adult male

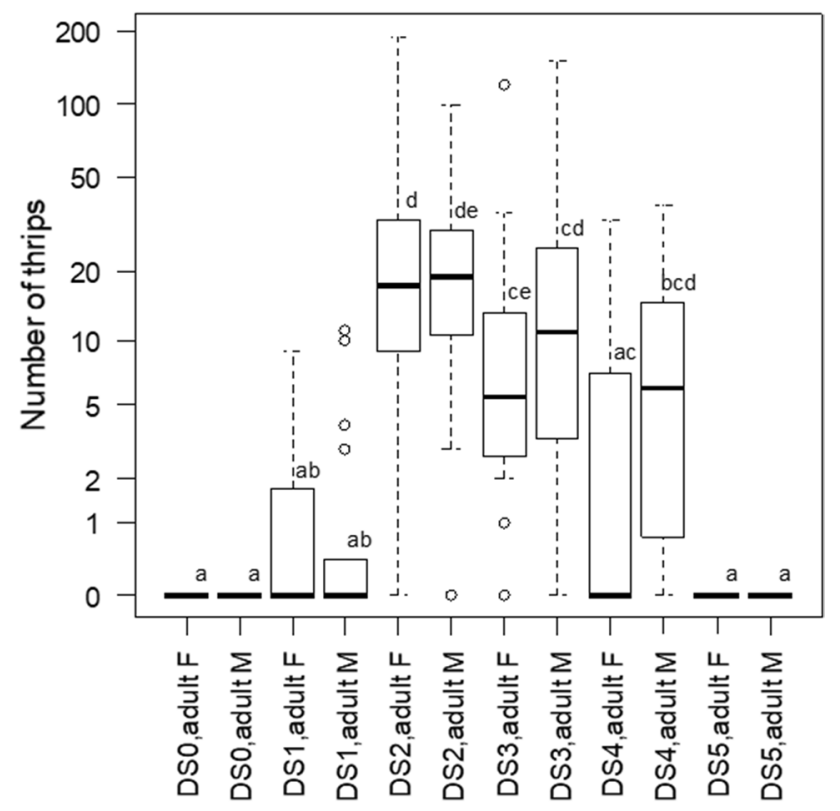

Fig. 2 Number of adult thrips (median \pm interquartile range) in inflorescences of $S$. nigra at six stages of floral development (DS0DS5), sampled June and July 2016. DS0 $(n=20)$, DS1 $(n=20)$, DS2 $(n=38)$, DS3 $(n=24)$, DS4 $(n=5)$, DS5 $(n=20)$, where DS0 $=$ inflorescences comprised of closed buds, DS $1 \leq 50 \%$ flowers open, DS2 $\geq 90 \%$ flowers open (pre-anthesis), DS3 $=100 \%$ flowers open (at anthesis), DS4 = flowers senescing, DS5=early fruit development. Significant difference between flower development stages (ANOVA, $F=70.45, P<0.0001$ ), Tukey's multiple comparison test indicates where differences lie (values with same letters are not significantly different)



Fig. 3 Number of life stages of thrips (median \pm interquartile range) in inflorescences of $S$. nigra at six stages of floral development (DS0 DS5), sampled June and July 2016. DS0 $(n=20)$, DS1 $(n=20)$, DS2 $(n=38)$, DS3 $(n=24)$, DS4 $(n=5)$, DS5 $(n=20)$. Significant difference between flower development stages (ANOVA, $F=74.61$, $P<0.0001$ ), Tukey's multiple comparison test indicates where differences lie (values with same letters are not significantly different)

and female thrips appeared in inflorescences as flower buds opened (DS0-DS1), and there was a significant increase when $100 \%$ flowers on inflorescence were at preanthesis stage (DS1-DS2: male and female, Tukey HSD $P<0.0001)$. Female numbers then fell as flowers reached anthesis (DS2-DS3: Tukey HSD female, $P<0.05$ ) suggesting females leave flowers at this point and continue to do so through to senescence (DS2-DS4, female, Tukey HSD $P<0.01)$. Male numbers were more stable from pre-anthesis to senescence (DS2-DS4: male, Tukey HSD $P>0.05$ ). All adult thrips were absent from inflorescences once petals had dropped and fruit developed (DS5).

Overall, there was no difference between relative numbers of adults and larvae in inflorescences at each flower development stage (Fig. 3. ANOVA, $F=0.07, P>0.05$ ), but numbers of each life stage varied as flowers developed (ANOVA, $F=5.01, P<0.001)$. As expected, adults appeared in inflorescences before the immatures (DS0-DS1). The number of adults and immatures increased significantly as all flowers opened (DS1-DS2: Tukey HSD, adults and immatures both, $P<0.0001)$. Larvae increased marginally as flowers reached anthesis and continue to increase as flowers begin senescence (DS2-DS3: Tukey HSD, immatures, $P>0.05$, DS2-DS4: immatures, $P<0.001)$. Larvae were not seen in young developing fruit (DS5) suggesting all thrips had left the inflorescences after senescence and as fruit developed. 


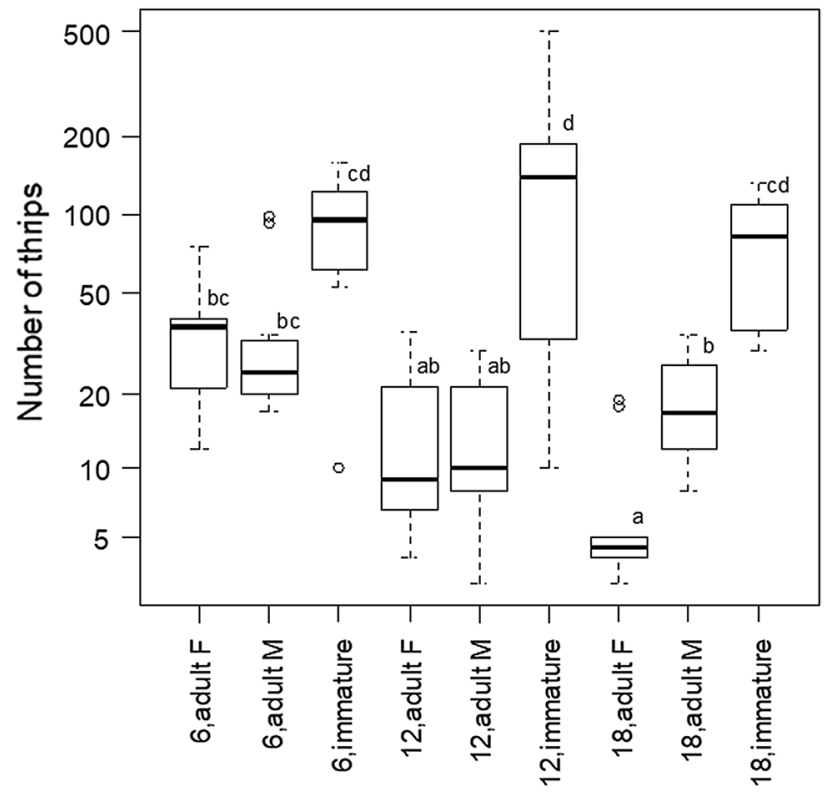

Fig. 4 Diurnal activity of thrips (median \pm interquartile range) in inflorescences of $S$. nigra. Collections of single inflorescences taken from 10 individual plant specimens repeated at 6:00, 12:00, and 18:00, showing different life stages of thrips foraging in flowers at specific times of the day. Significant differences between numbers of life stages and time of day (ANOVA, $F=4.12, P<0.01$ ), Tukey's multiple comparison test indicates where differences lie (values with same letters are not significantly different)

There was no significant difference between the proportions of adult male and female thrips present in inflorescences of $S$. nigra at 06:00 and 12:00 (Fig. 4: Tukey HSD, $P>0.05$ in both cases), however, female numbers were significantly lower than males at 18:00 (Tukey HSD, $P<0.05)$. Numbers of adult females in inflorescences of $S$. nigra decreased from early morning to evening (Tukey HSD, 06:00-12:00: $P<0.0001,12: 00-18: 00, P<0.05$ ) whereas numbers of male and immature thrips present in inflorescences remained consistent at each three sampling times (Tukey HSD, $P>0.05$ in all cases). Significantly more larvae than adults were recorded at 12:00 (Tukey HSD, $P<0.0001$, male and female) and at 18:00 (Tukey HSD, $P<0.0001$ female, $P<0.01$ male).

\section{Insect exclusion}

Inflorescences from which all insects had been excluded became desiccated after the 6-week exclusion period and no developing fruit were recorded (Fig. 5) whereas 33\% fruit-set was recorded in mesh bags that permitted access to flowers by thrips (or thrips-sized insects) compared to open pollinated inflorescences. Bagged inflorescences set

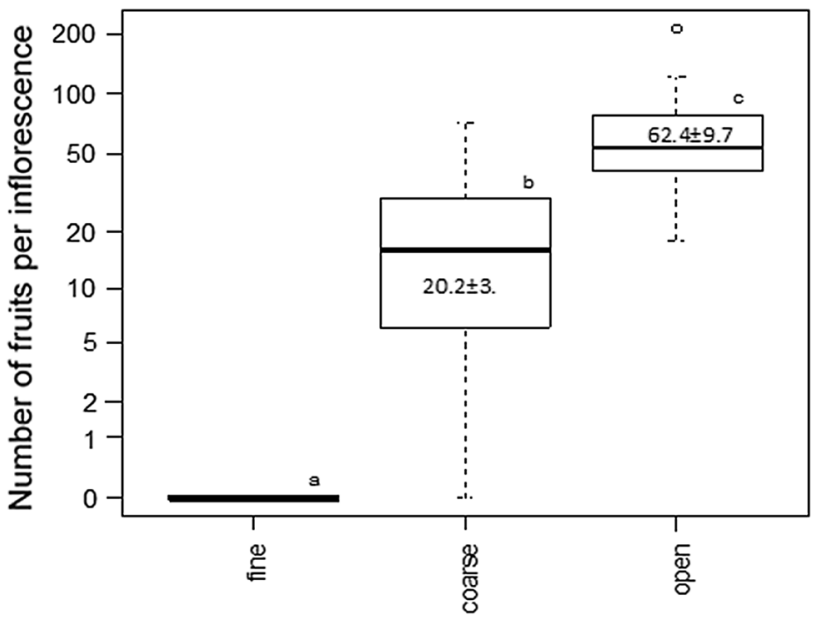

Fig. 5 Number of developing fruit (median \pm interquartile range) on inflorescences of $S$. nigra; inflorescences (1) uncovered (open), (2) covered by coarse nylon mesh bag (1 mm diam.), (3) covered by fine mesh bag $(0.125 \mathrm{~mm}$ diam.) for 6 weeks. Exclusion of thrips and small insects from inflorescences of $S$. nigra (3) prevented any fruitset occurring, with significantly less fruit developing in coarse mesh (2) than open inflorescences (1). ANOVA, mixed-effect model treating elders as true replicates (ANOVA $F=276.07, P<0.0001$ ), Tukey multiple comparison based on mixed-effect model used for compact letter display

significantly less fruit compared with open inflorescences [ANOVA $\log$ (fruit +1 ), $F=276.07, P<0.0001$ ], with significantly less fruit developing under fine mesh compared with course (Tukey HSD, $P<0.0001$ ) and course mesh compared with open inflorescences (Tukey HSD, $P<0.0001)$. Open inflorescences were accessible to other non-thysanopteran insect visitors and wind-transferred pollen although few other insect classes were observed during our sampling.

\section{Chemical analysis and insect bioassays}

\section{VOC emissions during floral development}

Floral scent of $S$. nigra was perceived as being most intense in the morning. Seven VOCs were detected in most odour collections (Table 1) but there were significant differences in the relative and absolute abundance of each compound emitted at inflorescence development stages, DS2-DS4 (ANOVA $F=2.4, P<0.01)$. The most abundant compound emitted from inflorescences with open flowers was linalool, which comprised over $40 \%$ of the total VOC collected at DS2-DS3. Linalool was significantly more abundant in odour emissions from inflorescences with open flowers than younger inflorescences with predominantly closed buds (Tukey HSD, $P=0.0185$ ). A gradual decline in linalool was evident at floral senescence although the decrease was not significant (Tukey HSD, $P=0.12$ ). Similarly, epoxy linalool and 
Table 1 Proportional abundance of component VOCs in total scent emissions collected over $24 \mathrm{~h}$ from developing inflorescences of S. nigra

\begin{tabular}{|c|c|c|c|c|c|c|}
\hline \multirow{2}{*}{$\begin{array}{l}\text { Floral volatile com- } \\
\text { pound }\end{array}$} & \multirow{2}{*}{$\begin{array}{l}\text { Retention } \\
\text { time (min) }\end{array}$} & \multirow{2}{*}{$\begin{array}{l}\text { Kovats } \\
\text { retention } \\
\text { index }\end{array}$} & \multicolumn{4}{|c|}{ Mean peak area (mean $\%$ of total volatile emission) } \\
\hline & & & DS0-DS1 (\%) & DS2-DS3 (\%) & DS4 (\%) & Control \\
\hline E-Ocimene & 6.09 & 1229 & $\begin{array}{c}1921.3 \pm 1238.9 \\
(19.3 \pm 11.2)\end{array}$ & $\begin{array}{l}44,291.3 \pm 14,792.7 \\
\quad(16.6 \pm 4.5)\end{array}$ & $\begin{array}{c}359.7 \pm 359.7 \\
(1.9 \pm 1.9)\end{array}$ & $0(0)$ \\
\hline Linalool oxide & 8.57 & 1416 & $\begin{array}{r}464.3 \pm 287.3 \\
(27.4 \pm 24.3)\end{array}$ & $\begin{array}{l}19,914.3 \pm 2728.8 \\
\quad(8.2 \pm 1.6)\end{array}$ & $\begin{array}{c}842.7 \pm 595.9 \\
(4.5 \pm 4.5)\end{array}$ & $0(0)$ \\
\hline Linalool & 9.88 & 1523 & $\begin{array}{c}454.8 \pm 454.8 \\
(3.6 \pm 3.6)\end{array}$ & $\begin{array}{l}112,011.0 \pm 15,904.8 \\
\quad(44.4 \pm 0.7)\end{array}$ & $\begin{array}{l}1886.3 \pm 1886.3 \\
(10 \pm 10)\end{array}$ & $0(0)$ \\
\hline Caryophyllene & 10.57 & 1580 & $0(0)$ & $0(0)$ & $0(0)$ & $274 \pm 274(13.3 \pm 13.3)$ \\
\hline Epoxy linalool & 12.03 & 1710 & $\begin{array}{c}608.5 \pm 359.9 \\
(6.5 \pm 3.8)\end{array}$ & $\begin{array}{l}54,882.3 \pm 54,882.3 \\
\quad(22.9 \pm 5.6)\end{array}$ & $\begin{array}{c}3221.3 \pm 3221.3 \\
(17.0 \pm 17.0)\end{array}$ & $0(0)$ \\
\hline Citronellol & 12.34 & 1739 & $\begin{array}{c}1745.3 \pm 1058.5 \\
(18.2 \pm 10.6)\end{array}$ & $\begin{array}{l}20,432.3 \pm 7821.6 \\
(7.9 \pm 2.7)\end{array}$ & $0(0)$ & $0(0)$ \\
\hline Caryophyllene oxide & 14.66 & 1965 & $0(0)$ & $0(0)$ & $0(0)$ & $757 \pm 757(36.7 \pm 36.7)$ \\
\hline
\end{tabular}

Differences were observed in abundance of each of the seven volatile compounds between flower development stages, DS2-DS4 (ANOVA $F=2.4, P<0.01$ )

citronellol were increasingly abundant in scent produced by inflorescences with open flowers (DS2-DS3) compared with senescing flowers (Tukey HSD, $P<0.05$ ); however, the abundance of each was similar in emissions retrieved from young inflorescences containing buds and the senescing flower stages (Tukey HSD, $P>0.05$ ). In summary, our data suggest that production of linalool increases as flowers in inflorescences open and declines as the flowers senesce. Citronellol and epoxy linalool were present in scent emitted from younger inflorescences still in bud, and levels increased marginally when buds opened, decreasing significantly as flowers senesced, reverting to levels recorded at the earlier floral development stages. All three of these VOCs were absent from leaves.

\section{Circadian abundance of floral VOCs}

The seven predominant compounds of the VOCs from inflorescences of $S$. nigra varied significantly (Table 2: ANOVA;
$F=19.29, P<0.001)$ and at each collection time (ANOVA; $F=6.25, P<0.01)$. The most abundant compound, linalool, made up $>50 \%$ of the total VOC at each time point. Our data suggest that linalool was less abundant in the afternoon but emissions increased during the evening, where absolute levels were greatest between 00:00 and 06:00. Our evidence suggests that the highest levels of linalool, occurring from inflorescences at DS2 peaked between midnight and 06:00, coinciding with the highest abundance of adult female thrips in inflorescences (Figs. 2 and 4).

\section{Olfactory tests with floral VOCs}

VOCs from inflorescences at DS2, collected from 00:00 to 06:00 were chosen by thrips significantly more often than by chance, after Bonferroni correction (80.0\% of choices; binomial test, $z=4.52, P<0.0001$, corrected $\alpha=0.01$ ) (Fig. 6). While thrips also chose DS3 volatiles collected over $24 \mathrm{~h} 61.7 \%$ of the time, this was not significant after

Table 2 Proportional abundance of component VOCs in total scent emissions collected from an inflorescence of S. nigra (DS2 $>90 \%$ flowers open) at four time intervals, over $24 \mathrm{~h}$

\begin{tabular}{|c|c|c|c|c|c|c|}
\hline \multirow[t]{2}{*}{ Floral volatile compound } & \multirow{2}{*}{$\begin{array}{l}\text { Retention time } \\
\text { (min) }\end{array}$} & \multirow{2}{*}{$\begin{array}{l}\text { Kovats retention } \\
\text { index }\end{array}$} & \multicolumn{4}{|c|}{ Peak area (\% of total volatile emission) } \\
\hline & & & 12:00-18:00 & 18:00-00:00 & 00:00-06:00 & $06: 00-12: 00$ \\
\hline E-Ocimene & 6.091 & 1229 & $2734(5)$ & $7449(5)$ & $21,404(6)$ & $5117(4)$ \\
\hline Linalool oxide & 8.569 & 1416 & $5182(9)$ & $7202(5)$ & $19,921(6)$ & $7268(5)$ \\
\hline Linalool & 9.876 & 1523 & $33,672(58)$ & $90,866(61)$ & $190,292(55)$ & $81,471(58)$ \\
\hline Caryophyllene & 10.566 & 1580 & $0(0)$ & $0(0)$ & $4266(1)$ & $0(0)$ \\
\hline Epoxy linalool & 12.029 & 1710 & $13,874(24)$ & $37,326(25)$ & $92,056(26)$ & 40,633 (26) \\
\hline Citronellol & 12.340 & 1739 & $2858(5)$ & $7263(5)$ & $16,760(5)$ & $6232(5)$ \\
\hline Caryophyllene oxide & 14.664 & 1965 & $0(0)$ & $0(0)$ & $4056(1)$ & $0(0)$ \\
\hline Total peak area & & & $58,320(100)$ & $150,106(100)$ & $348,755(100)$ & $140,721(100)$ \\
\hline
\end{tabular}


Fig. 6 Thrips selection preference using a y-tube olfactometer for testing volatile extractions of $S$. nigra floral development stages (DS0-DS3) against control. Bars indicate number of individuals choosing each arm. $* * * P<0.001$



the Bonferroni correction was applied (binomial test, $z=1.68, P=0.0466$, corrected $\alpha=0.01)$. A $X^{2}$ test revealed no significant differences between responses to different levels of partially open inflorescences $\left(X^{2}=4.251\right.$, $P=0.1193$ ) so these were pooled (DS1) for analysis. Thrips were not attracted to partially open inflorescences (binomial test, $z=1.17, P=0.1226$ ) or those with closed buds $(z=0.90, P=0.1891)$.

\section{CNglcs and floral development}

\section{Defence compounds in floral tissue of S. nigra}

Sambunigrin and prunasin were detected in reproductive tissue sampled at all development stages examined (Suppl. Fig. S3). Prunasin occurred at very low concentrations ranging from 1.2 to $1.3 \mu \mathrm{g} \mathrm{mg}^{-1}$ (fresh tissue weight) in buds and senescing flowers to 0.8 and $0.3 \mu \mathrm{g} \mathrm{mL}^{-1}$ in open flower tissue and mature red fruit, respectively. Sambunigrin was recorded at significantly higher concentrations than prunasin (KW, $H=6.19, P<0.05$ ) in all $S$. nigra floral tissue; up to 50 times more concentrated when compared at each flower development stage.

The concentration of sambunigrin was highest in the young bud tissue of $S$. nigra and decreased as flower development progressed and flowers opened (Fig. 7a; DS0 vs DS1 and DS2-3: $M W, U=0, P<0.001$ in both cases). As flowers matured and petal drop initiated the level of sambunigrin increased again to levels similar to those found in the flower buds (DS4 vs DS0; MW, $U=6, P>0.05$ ).

Similarly the concentration of prunasin was significantly higher in young bud tissue, decreasing in larger buds and as flowers open (Fig. 7b, DS0 vs DS1, MW $U=1, P<0.01$ ) with a significant increase as flowers progressed in age (DS1 vs DS2-3, MW, $U=2, P<0.01$ ) increasing further in senescing flowers returning to levels present in young buds (DS2-3 vs DS4, MW, $U=1, P<0.05)$. As with sambunigrin there was a decreasing trend in the concentration of prunasin, comparing senescing flower tissue to green fruit and mature red fruit but this decrease was not significant (DS4 vs DS5 and mature fruit; $\mathrm{MW}, U=0, P>0.05$ ).

\section{Effect of CNglcs on feeding preference (dual-choice test)}

Extracts of green fruit, buds and leaves of $S$. nigra deterred adult female thrips from treated flowers (binomial test, $z=0$, $P<0.001 ; z=0.179, P<0.01 ; z=0.134, P<0.001$, respectively), yet the thrips were selective for $100 \%$ open flowertreated extracts over controls (DS3) (binomial test, $z=0.134$, $P<0.01)$. Assays undertaken with isolated $\mathrm{CNglcs}$ indicated thrips preferred flowers which had not been treated with either prunasin ( $90 \%$ selecting control) or sambunigrin $(67 \%$ selecting control). Prunasin was highly deterrent to thrips under these conditions even at the lowest concentration applied 
Fig. 7 Concentration $\left(\mu \mathrm{g} \mathrm{mg}^{-1}\right.$ FW) of CNglcs. Sambunigrin (a) and prunasin (b) (mean $\pm \mathrm{SE}$ ), plotted against mean no. adult thrips (male and female combined, mean $\pm S E$ ) in developing reproductive tissue of $S$. nigra. Floral development stages DS0-DS5 and mature red fruit, sampled June and July 2016, DS0 $(n=9)$, DS1 $(n=6)$, DS 2 and DS 3 combined $(n=9)$, DS4 $(n=3)$, DS5 $(n=3)$ and DSO $=$ closed bud, DS $1=<50 \%$ flowers in inflorescence open, DS2 $\geq 90 \%$ flowers open (preanthesis), DS3 $=100 \%$ flowers open (at anthesis), DS4 = senescence, DS5 = early development of green fruit mature red fruit $(n=3)$, where
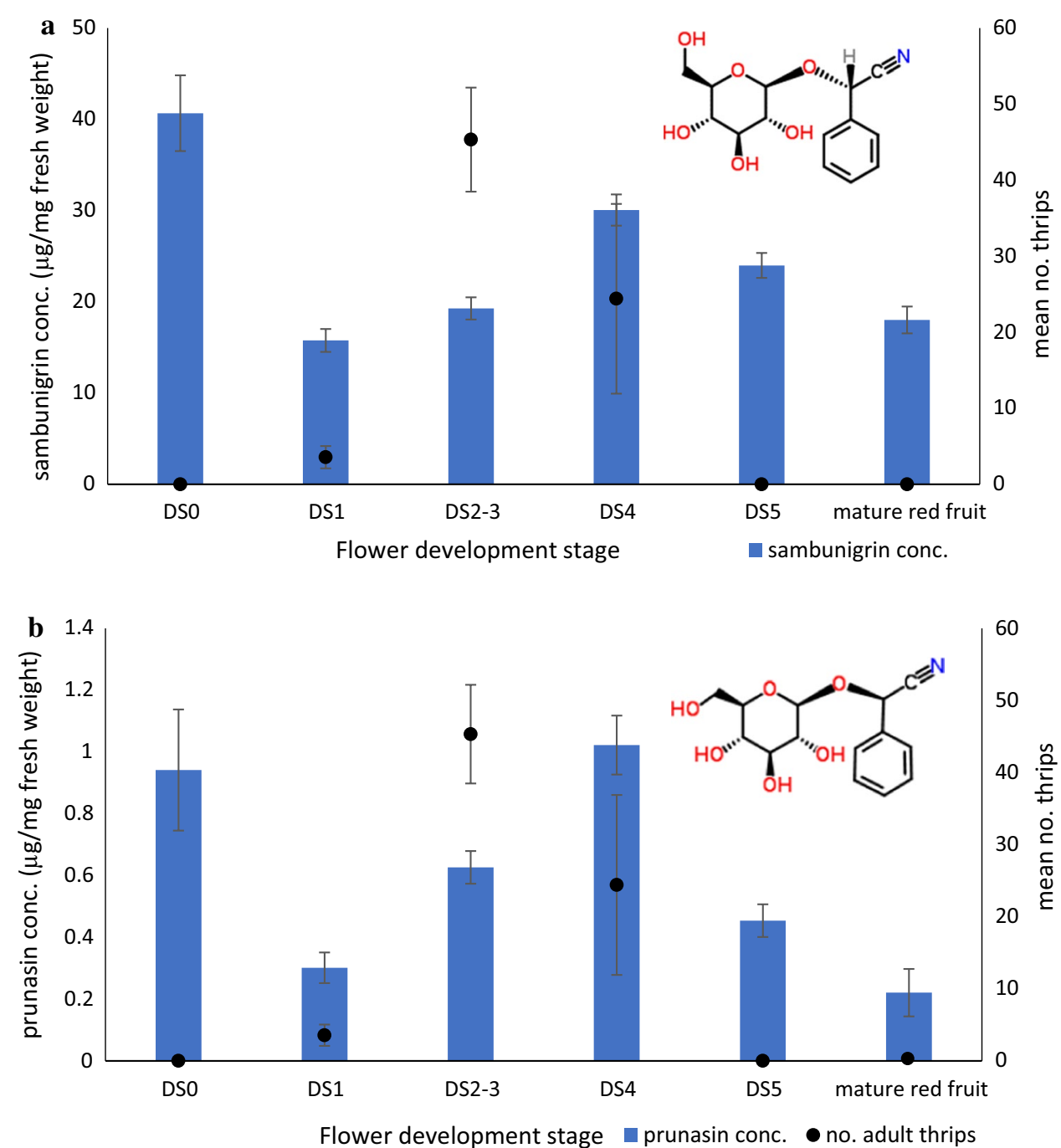

( $z=4.32, P<001)$. In contrast, sambunigrin was found only to be deterrent at the highest concentration tested (binomial test, $z=2.65, P<0.01$, corrected $\alpha=0.01$, Table 3 ).

thrips selecting CNglc-treated (T) and untreated (C) flowers

\begin{tabular}{llllll}
\hline $\begin{array}{l}\text { Treatment }(\mathrm{T}) \\
\left(\mu \mathrm{g} \mathrm{mL}^{-1}\right)\end{array}$ & $\begin{array}{l}\text { Conc. } \\
\left(\mu \mathrm{gL}^{-1}\right)\end{array}$ & $\begin{array}{l}\text { Number } \\
\text { of thrips }\end{array}$ & $z$ value & $p$ value \\
\cline { 2 - 5 } & & $(T)$ & $(C)$ & \\
\hline Prunasin & 0.1 & 1 & 12 & 4.32 & $0.001^{* * * *}$ \\
& 1 & 2 & 20 & 5.43 & $0.001^{* * *}$ \\
& 10 & 1 & 12 & 4.32 & $0.001^{* * *}$ \\
& 100 & 2 & 15 & 4.46 & $<0.0001^{* * *}$ \\
& 0.1 & 5 & 11 & 2.12 & 0.034 \\
& 1 & 10 & 17 & 1.91 & 0.057 \\
& 10 & 5 & 11 & 2.12 & 0.034 \\
& 100 & 7 & 16 & 2.65 & $0.008^{* * *}$ \\
\hline
\end{tabular}

Total 147 thrips included in analysis. Thrips exposed to residues of prunasin and sambunigrin solutions, $100 \mu \mathrm{L}$ applied at $0.1,1,10$, and $100 \mu \mathrm{g} \mathrm{mL}^{-1}$

$* * P<0.01$ and $* * * P<0.001$

\section{Discussion}

Thrips are ancient pollen feeders (Penalver et al. 2012) and it is widely acknowledged that pollen evolved as the first reward for early insect mutualists (Labandeira 1998; Grimaldi 1999). Shorea spp. (Dipterocarpaceae) (Proctor et al. 1996) provide a well-documented example of a thrips brood-site mutualism, where trees produce high volumes of flowers over a relatively short period coinciding with the rapid build-up of large thrips populations which transfer pollen to new hosts as flowers die. In our study we observed high numbers of adult thrips visiting the inflorescences of $S$. nigra, coinciding with the peak release of VOCs attractive to thrips, when flowers were at 
pre-anthesis and were pollen-receptive. Larvae increased in number, exceeding adult numbers as flowers in inflorescences matured. The longevity of the $S$. nigra inflorescences provided an environment for T. major to develop from egg to winged-adult stage at summer temperatures (see Lewis 1973), increasing the likelihood of thrips moving in and between host plants. We found that excluding all insect visitors from $S$. nigra inflorescences prevented fruit-set whereas allowing thrips access to flowers significantly increased the chances of fruit developing. Thrips were absent from flowers of S. nigra at petal-drop, which coincided with concentrations of $\mathrm{CNglcs}$ in mature flowers and developing fruits that were deterrent to adult thrips. Thus, our data suggest that the floral chemistry of $S$. nigra mediates this interaction and also that thrips are contributing to the pollination of this plant. There is precedent for this since multiple interacting factors causing pollinator decline and absence in floral life-cycles have previously been associated with changes in floral chemistry (Raguso and Pichersky 1999; Terry et al. 2007) and diminishing rewards (Schiestl and Ayasse 2001).

Phylogenetic evidence, as well as taxonomic and biogeographical distributions, suggest that all insect-plant mutualisms are not only frequently gained, but also frequently lost; for example, the shift in reliance on alternative abiotic pollination strategies (wind pollination and self-pollination). Mutualisms can establish in habitats where relevant pollinating taxa are abundant, alternative mutualists rare or where the benefit of mutualistic service is high (see Bronstein et al. 2006). Many previous general literature sources on flowering plants and pollination have overlooked the presence of large numbers and association of thrips with flowers and incorrectly assigned pollination function to wind or bees, even in the absence of bees (see Knuth 1906; Hagerup and Hagerup 1953). One example is the pollination of Acer pseudoplatanus L. (Sapindaceae) which was attributed in part to wind by Binggeli (1992) and insects such as bees and flies (Binggeli 1992; Proctor et al. 1996) although these insects were rarely observed during a detailed study of this species (Tal 2009). While wind probably contributed to the pollination of $A$. pseudoplatanus (Hesse 1979), Tal (2009) highlighted that wind pollination had been previously inferred on the basis that pollination still occurred after exclusion of insects with nets of $1 \mathrm{~mm}$ mesh size (Binggeli 1992), an aperture size that would not exclude thrips. Although pollen deposition by non-bee pollinators is often recorded lower than bees, high visitation frequency as occurs with thrips can reduce this deficit (Rader et al. 2016), with some species capable of carrying > 100 grains per insect (Ananthakrishnan 1982; Velayudhan and Annadurai 1986). Thrips often forage at night (Kirk 1997), leaving flowers as ambient temperature rises by day. In inflorescences of $S$. nigra female thrips numbers were recorded at highest levels at 06:00 and decreased throughout the day, while numbers of males and immatures remained stable. Although this study did not track the direction of movement of female thrips within or between inflorescences of $S$. nigra, such circadian dispersal activity of insects facilitates pollen transfer to conspecific flowers.

Exclusion of thrips from the developing $S$. nigra inflorescences using fine-mesh nets resulted in an absence of developing fruits, despite the mesh pore-size capable of accommodating wind-transmitted pollen grains (Bolli 1994). In contrast, fruit-set readily occurred when inflorescences were uncovered and accessible to pollen transmission (wind and all insect visitors) and when inflorescences were contained within course mesh nets $(1 \mathrm{~mm})$, which allowed access to thrips and wind-blown pollen but excluded larger insects. Slight reduction in pollination occurring with course mesh coverage may be partially attributed to thrips being physically hindered by the mesh bags, with some pollen removal possible during entry. While Wragg and Johnson (2011) noted that seed set in wind- and insect-pollinated Cyperus spp. was unaffected by the use of pollination bags, Wassnera and Ravetta (2005) suggest that mesh bags may reduce air movement, increase humidity and light transmission and that chemistry may be affected influencing insect behaviour. However, experimental exclusion of thrips from flowers in pollinator studies is infrequently reported because of technical difficulties in containing such small, highly mobile organisms and thus it is likely that the full significance of thrips in plant reproduction remains considerably underestimated.

Floral scents act as signalling cues for both pollinators and antagonists (Theis and Adler 2012; Kessler et al. 2015). To increase chances of pollen transmission to receptive flowers, floral ontogenical changes in chemistry can also be mechanistic in directing pollinators to unpollinated flowers (Schiestl and Ayasse 2001). Of the comprehensive list of volatile organic compounds (VOCs) previously recorded from flowers of S. nigra (Kaack et al. 2006; Salvador et al. 2017), few report VOCs emitted from intact inflorescences (Knudsen et al. 2006; Peñuelas et al. 2014). Here we monitored seven key volatile compounds from inflorescences in situ over $24 \mathrm{~h}$. Linalool was the most abundant of the VOCs, peaking when flowers in inflorescence were open (pre-anthesis), while almost absent when at bud and senescence stages; corresponding with the abundance of thrips in inflorescences. The abundance of linalool in S. nigra inflorescence volatile emissions increased between midnight and early morning coinciding with peak visitation by female thrips to flowers. The attraction of T. major to $S$. nigra by linalool emitted from inflorescences with open flowers is supported by previous studies reporting the attraction of Thrips obscuratus (Crawford) to Japanese honeysuckle flowers, Lonicera japonica (Thunberg) (Caprifoliaceae) (El-Sayed et al. 2009), which have been shown to emit high 
levels of linalool at night (Miyake et al. 1998). An additional monoterpenoid of interest present was $\beta$-ocimene. This ubiquitous VOC emitted from plant reproductive structures and vegetative tissue by numerous species of plants (Knudsen et al. 2006) has several ecological functions including pollination attraction (Filella et al. 2013; Farré-Armengol et al. 2017). Terry et al. (2007) demonstrated and quantified the coordination between the release of VOCs, which included two isomers of $\beta$-ocimene from the male cones of Macrozamia lucida LAS Johnson, and the behaviour of their hostspecific thrips pollinators; Cycadothrips chadwicki Mound. Our study suggests that while female thrips responded to varying levels of the key components of the VOCs emitted by $S$. nigra inflorescences, male and immature thrips remained constant in numbers in inflorescences of $S$. nigra throughout the circadian cycle despite the fluctuation in emission of these compounds.

Mutualisms can develop where trade-offs between partners are reduced. Although there are isolated cases of $T$. major causing damage to crop hosts in its native range, when such cases are reported they are usually present in conjunction with invasive species of thrips (OEPP, EPPO 2004). Production of defence compounds to protect valuable reproductive tissue from pollen-feeding flower visitors can be a highly efficient strategy to preserve gametes and developing embryos (Sedivy et al. 2012), particularly when resources are deployed for their production at critical times in development (McCall and Fordyce 2010). CNglcs ( $\alpha$-hydroxynitrile glucosides) and their activating $\beta$-glucosidases occur in tissues of $S$. nigra (Velíšek et al. 1981; DellaGreca et al. 2000). These phytoanticipin compounds (VanEtten et al. 1994) are spatially separated at a cellular level until activated and releasing hydrogen cyanide (cyanogenesis) through tissue disruption such as insect feeding (Zagrobelny et al. 2004; Møller 2010). We recorded two CNglcs, prunasin and sambunigrin, in floral tissues of $S$. nigra and showed that these compounds were at the lowest levels when the flower was receptive to fertilisation (pre-anthesis) and adult thrips accumulated in flowers, while levels increased in developing buds and at fruit-set when thrips were absent. CNglcs are established feeding deterrents (Zagrobelny et al. 2004) and our bioassays confirmed that adult thrips were deterred by the presence of sambunigrin, the dominant $\mathrm{CNglc}$, at relatively high concentrations. No behavioural effects were observed when sambunigrin was presented at lower concentrations similar to those recorded in newly opened flowers. Therefore, $\mathrm{CNglcs}$ in the floral tissue of $S$. nigra may play a role in protecting unopened flower buds and developing fruit from potential florivores. While we can postulate that defence of valuable tissues is the primary role of CNglcs, the multifunctionality of these compounds as a source for sugars and reduced nitrogen for the physiological changes that occur during the reproductive stages (Selmar et al. 1988; Neilson et al. 2013; Del Cueto et al. 2017) has not been considered here. To ameliorate the costs of chemical defence, secondary metabolites that initially served defence purposes may acquire new functions in host-insect recognition or be recruited as storage compounds that are mobilized when needed to counteract imbalances in primary metabolism (Zagrobelny et al. 2008).

\section{Conclusions}

S. nigra floral traits are consistent with it being pollinated by thrips (see Kirk 1997) such as compact inflorescences (De Jong 1976), many flowers per inflorescence, abundant and powdery pollen (Hesse 1979). If thrips provide a pollination service to $S$. nigra, then this will likely manifest in traits that attract the pollinating taxa at temporally critical points in floral development. The combination of field and laboratory experiments with chemical analysis of floral tissue provided an innovative approach to our original research question 'Do thrips provide a pollination service to Sambucus nigra'? Here we provide new evidence that the floral chemistry of $S$. nigra attracts a flower-feeding thrips to pollen-receptive flowers in high numbers and then deters them before fruit development. In addition, visitation by thrips increases the chances of fruit-set in this species. In return the plant provides thrips with sites for oviposition and a food source for developing larvae.

Opportunistic mutualisms arising between insects and predominantly wind-pollinated genera within closed habitats have shown that plants can transfer from wind pollination to insect pollination in certain ecosystems (Wallander 2008; Wragg and Johnson 2011), with plant-trait shifts occurring after transition, as an adaptation to enhance efficiency of a new pollination mode. Understanding what drives these shifts in pollination strategies can enable future investigations into studies which examine more complex relationships between land-use change and plant health, particularly as mutualisms are known to become antagonistic if ecological conditions change (Bronstein et al. 2006).

Author contribution statement AS planned the research, undertook field sampling, laboratory experiments and analysis of data. DWC provided taxonomic identification of insects. SA analysed olfactory bioassay data and GK and IF provided LCMS technical assistance undertaken in PS lab. AS wrote manuscript with all authors editing and approving the final manuscript. 
Acknowledgements The Fellowship was supported by the Royal Botanic Gardens Kew and we are grateful for an award from the Royal Horticultural Society (Coke Trust Bursary) which enabled the initial thrips-survey work. We also thank Stephen Young, University of Greenwich for statistical guidance. The draft of this manuscript was improved with advice and comments from the journal reviewers and we are grateful to them for their suggestions which aided the final revision.

Open Access This article is distributed under the terms of the Creative Commons Attribution 4.0 International License (http://creativeco mmons.org/licenses/by/4.0/), which permits unrestricted use, distribution, and reproduction in any medium, provided you give appropriate credit to the original author(s) and the source, provide a link to the Creative Commons license, and indicate if changes were made.

\section{References}

Ananthakrishnan TN (1982) Thrips and pollination biology. Curr Sci 5:168-172

Ananthakrishnan TN (1984) Bioecology of thrips. Indira Publishing House, Michigan, p 233

Ashton PS, Givnish TJ, Appanah S (1988) Staggered flowering in the Dipterocarpaceae: new insights into floral induction and the evolution of mast fruiting in the aseasonal tropics. Am Nat 132(1):44-66

Atkinson MD, Atkinson E (2002) Biological flora of the British Isles: Sambucus nigra L. J Ecol 90:895-923

Binggeli P (1992) Patterns of invasion of sycamore (Acer pseudoplatanus L.) in relation to species and ecosystem attributes. $\mathrm{PhD}$ thesis, Ulster

Bolli R (1994) Revision of the genus Sambucus. Diss Bot 223:1-227

Boucher DH, James S, Keeler KH (1982) The ecology of mutualism. Annu Rev Ecol Syst 13:315-347

Bronstein JL, Alarcón R, Geber M (2006) The evolution of plant-insect mutualisms. New Phytol 172:412-428

Charlebois D, Byers PL, Finn CE, Thomas AL (2010) Elderberry: horticulture, botany, potential. Hortic Rev (Am Soc Hortic Sci) $37: 213-280$

Dammer U (1890) Die extrafloralen nectarine an Sambucus nigra. Plant Syst Evol 40:261-264

Darwin CR (1876) The effects of cross and self-fertilization in the vegetable kingdom. John Murray, London

De Jong PC (1976) Flowering and sex expression in Acer L.-a biosystematic study. Mededelingen landbouwhogeschool, Wageningen, pp 76-82

Del Cueto J, Ionescu IA, Pičmanová M, Gericke O, Motawia MS, Olsen CE, Campoy JA, Dicenta F, Møller BL, Sánchez-Pérez $\mathrm{R}$ (2017) Cyanogenic glucosides and derivatives in almond and sweet cherry flower buds from dormancy to flowering. Front Plant Sci 8:800. https://doi.org/10.3389/fpls.2017.00800

DellaGreca M, Fiorentino A, Monaco P, Previtera L, Simonet AM (2000) Degraded cyanogenic glucosides from Sambucus nigra. Tetrahedron Lett 41:6507-6510

Donoghue MJ, Bell CD, Winkworth RC (2003) The evolution of reproductive characters in Dipsacales. Int J Plant Sci 164(S5):S453-S464

El-Sayed AM, Mitchell VJ, McLaren GF, Manning LM, Bunn B, Suckling DM (2009) Attraction of the New Zealand flower thrips, Thrips obscuratus, to cis-jasmone, a volatile identified from Japanese honeysuckle flowers. J Chem Ecol 35:656-663

Endress PK (1994) Diversity and evolutionary biology of tropical flowers. Cambridge University Press, Cambridge
Farré-Armengol G, Filella I, Llusià J, Peñuelas J (2017) B-ocimene, a key floral and foliar volatile involved in multiple interactions between plants and other organisms. Molecules 22:1148

Filella I, Primante C, Llusià J, Martín González AM, Seco R, FarréArmengol G, Rodrigo A, Bosch J, Peñuelas J (2013) Floral advertisement scent in a changing plant-pollinators market. Sci Rep 3:3434

Fukuhara T, Tokumaru S (2014) Inflorescence dimorphism, heterodichogamy and thrips pollination in Playcarya strobilacea (Juglandaceae). Ann Bot 133:467-476

Grimaldi D (1999) The co-radiations of pollinating insects and angiosperms in the Cretaceous. Ann Mo Bot Gard 86(2):373-406

Grime JP, Hodgson JG, Hunt R (1988) Comparative plant ecology: a functional approach to common British species. Unwin-Hyman, London

Gross CL (2005) Pollination efficiency and pollinator effectiveness. In: Dafni A, Kevan PG, Husband BC (eds) Practical pollination biology. Enviroquest, Cambridge, pp 354-363

Hagerup E, Hagerup O (1953) Thrips pollination of Erica tetralix. New Phytol 52:1-7

Hesse M (1979) Ultrastructure and distribution of pollenkitt in the insect- and wind-pollinated genus Acer (Aceraceae). Plant Syst Evol 131:277-289

Infante F, Ortız JA, Solis-Montero L, Mound LA, Vega FE (2017) Thrips (Thysanoptera) of coffee flowers. Ann Entomol Soc Am 110(3):329-336

Johnson SD, Steiner KE (2000) Generalization versus specialization in plant pollination systems. Trends Ecol Evol 15(4):140-143

Kaack K, Christensen LP, Hughes M, Eder R (2006) Relationship between sensory quality and volatile compounds of elderflower (Sambucus nigra L.) extracts. Eur Food Res Technol 233:57-70

Kessler D, Kallenbach M, Diezel C, Rothe E, Murdock M, Baldwin IT (2015) How scent and nectar influence floral antagonists and mutualists. eLife 4:e07641. https://doi.org/10.7554/elife.07641

Kirk WDJ (1988) Thrips and pollination biology. In: Ananthakrishnan TN, Raman A (eds) Dynamics of insect-plant interaction. Recent advances and future trends. Oxford and IBH, New Delhi, pp 129-135

Kirk WDJ (1997) Feeding. In: Lewis T (ed) Thrips as crop pests. CAB International, University Press Cambridge, Cambridge, pp 119-174

Knudsen JT, Eriksson R, Gershenzon J, Ståhl B (2006) Diversity and distribution of floral scent. Bot Rev 72:1-120

Knuth P (1906) Handbook of flower pollination. Clarendon Press, Oxford

Labandeira CC (1998) Early history of arthropod and vascular plant associations. Annu Rev Earth Planet Sci 26(1):329-377

Lewis T (1973) Thrips their biology, ecology and economic importance. Academic Press Inc, London, p 349

McCall AC, Fordyce JA (2010) Can optimal defence theory be used to predict the distribution of plant chemical defences? J Ecol 98:985-992

Mitchell RJ, Irwin RE, Flanagan RJ, Karron JD (2009) Ecology and evolution of plant-pollinator interactions. Ann Bot 103:1355-1363

Miyake T, Yamaoka R, Yahara T (1998) Floral scents of hawkmothpollinated flowers in Japan. J Plant Res 111:199-205

Møller BL (2010) Functional diversifications of cyanogenic glucosides. Curr Opin Plant Biol 13(3):337-346

Moog U, Fiala B, Federle W, Maschwitz U (2002) Thrips pollination of the dioecious ant plant Macaranga hullettii (Euphorbiaceae) in southeast Asia. Am J Bot 89:50-59

Morison GD (1968) Observations and records for some British Thysanoptera VII. Thripidae, Thrips flavus Schrank and Thrips brevicornis Priesner. The Entomol 101:205-212 
Mound LA, Terry I (2001) Thrips pollination of the central Australian Macrozamia macdonnelii (Cycadales). Int J Plant Sci 162:147-154

Mound LA, Morison GD, Pitkin BR, Palmer JM (1976) Thysanoptera. Handbooks for the identification of British insects I:11, vol 56. Royal Entomological Society, London, pp 1-79

Mound LA, Collins DW, Hastings A (2018) Thysanoptera Britannica et Hibernica - Thrips of the British Isles. Lucidcentral.org, Identic Pty Ltd, Queensland, Australia. https://keys.lucidcentral.org/keys/ v3/british_thrips/. Accessed 4 Sept 2016

Neilson EH, Goodger JQD, Woodrow IE, Møller BL (2013) Plant chemical defense: at what cost? Trends Plant Sci 18(5):250-258

OEPP, EPPO (2004) Good plant protection practice PP 2/33. OEPP/ EPPO Bull 34:425-426

Ollerton J, Killick A, Lamborn E, Watts S, Whiston M (2007) Multiple meanings and modes: on the many ways to be a generalist flower. Taxon 56(3):717-728

Penalver E, Labandeira C, Barron E, Delclos X, Nel P, Nel A, Tafforeau P, Soriano C (2012) Thrips pollination of Mesozoic gymnosperms. Proc Natl Acad Sci USA 109(22):8623-8628

Peñuelas J, Farré-Armengol G, Llusia J, Gargallo-Garriga A, Rico L, Sardans J, Terradas J, Filella I (2014) Removal of floral microbiota reduces floral terpene emissions. Sci Rep 4:6727

Proctor M, Yeo P, Lack A (1996) The natural history of pollinators. HarperCollins Publishers, London

R Core Team (2016) R: a language and environment for statistical computing. R Foundation for Statistical Computing, Vienna, Austria. https://www.R-project.org/. Accessed 4 Mar 2017

Rader R, Bartomeus I, Garibaldi LA, Garratt MPD, Howlett BG et al (2016) Non-bee insects are important contributors to global crop pollination. Proc Natl Acad Sci USA 113(1):146-151

Raguso RA, Pichersky E (1999) A day in the life of linalool molecule: chemical communication in a plant-pollinator system. Part 1: linalool biosynthesis in flowering plants. Plant Species Biol $14: 95-120$

Raspudić E, Ivezić M, Brmež M, Trdan S (2009) Distribution of Thysanoptera species and their host plants in Croatia. Acta Agric Slov 93(3):275-283

Sakai S (2002) A review of brood-site pollination mutualism: plants providing breeding sites for their pollinators. J Plant Res 115:161-168

Salvador Â, Silvestre A, Rocha S (2017) Unveiling elderflowers (Sambucus nigra L.) volatile terpenic and norisoprenoids profile: effects of different postharvest conditions. Food Chem 229:276-285

Schiestl FP, Ayasse M (2001) Post-pollination emission of a repellent compound in a sexually deceptive orchid: a new mechanism for maximising reproductive success? Oecologia 126:531-534

Sedivy C, Piskorski R, Müller A, Dorn S (2012) Too low to kill: concentration of the secondary metabolite ranunculin in buttercup pollen does not affect bee larval survival. J Chem Ecol 38:996-1002

Selmar D, Lieberei R, Biehl B (1988) Mobilization and utilization of cyanogenic glycosides: the Linustatin Pathway. J Plant Physiol 86:711-716

Tal O (2009) Acer pseudoplatanus (Sapindaceae): heterodichogamy and thrips pollination. Plant Syst Evol 278:211-221

Terry LI, Walter GH, Moore CJ, Roemer RB, Hull C (2007) Odormediated push-pull pollination in cycads. Science 318(5847):70
Teulon DAJ, Penman DR (1990) Host records for the New Zealand flower thrips (Thrips obscuratus (Crawford) Thysanoptera: Thripidae). N Z Entomol 13(1):46-51. https://doi.org/10.1080/00779 962.1990 .9722591

Theis N, Adler LS (2012) Advertising to the enemy: enhanced floral fragrance increases beetle attraction and reduces plant reproduction. Ecology 93(2):430-435

VanEtten HD, Mansfield JW, Bailey JA, Farmer EE (1994) Two classes of plant antibiotics: Phytoalexins versus "Phytoanticipins". Plant Cell 6(9):1191-1192

Velayudhan R, Annadurai RS (1986) Pollination potential of thrips (Insecta: Thysanoptera) in some Solanaceous plants. Proc Indian Acad Sci 95:109-116

Velayudhan R, Annadurai RS (1987) Pollen transfer and stigma receptivity with reference to thrips (Insecta: Thysanoptera) in Solanum melongena Linn. Curr Sci 56:287-289

Velíšek J, KubelkaV Pudil F, Svobodova Z, Davidek J (1981) Volatile constituents of elder (Sambucus nigra L.) 1. Flowers and leaves. Lebensm Wiss Technol 14(6):309-312

Vierbergen G, Kucharczyk H, Kirk WDJ (2010) A key to the second instar larvae of the Thripidae of the Western Palaearctic region (Thysanoptera). Tijdschr Entomol 153:99-160

Vogel S (1978) Floral ecology. In: Ellenberg H, Esser K, Merxmüller H, Schnepf E, Ziegler H (eds) Progress in botany/Fortschritte der Botanik, vol 40. Springer, Berlin, Heidelberg, pp 453-481

Wallander E (2008) Systematics of Fraxinus (Oleaceae) and evolution of dioecy. Plant Syst Evol 273(1):25-49

Ward LK (1973) Thysanoptera occurring in flowers of a chalk grassland. Entomologist 106(1320):97-113

Waser NM, Ollerton J (2006) Plant-pollinator interactions: from specialization to generalization. University of Chicago Press, Chicago, p 445

Waser NM, Chittka L, Price MV, Williams NM, Ollerton J (1996) Generalization in pollination systems, and why it matters. Ecol Soc Am 77(4):1043-1060

Wassnera DF, Ravetta DA (2005) Temperature effects on leaf properties, resin content, and composition in Grindelia chiloensis (Asteraceae). Ind Crops Prod 21:155-163

Williams G, Adam P (1994) A review of rainforest pollination and plant-pollinator interactions with particular reference to Australian subtropical rain forests. Aust Zool 29:177-212

Wragg PD, Johnson SD (2011) Transition from wind pollination to insect pollination in sedges: experimental evidence and functional traits. New Phytol 191:1128-1140

Yamasaki E, Sakai S (2013) Wind and insect pollination (ambophily) of Mallotus spp. (Euphorbiaceae) in tropical and temperate forests. Aust J Bot 61(1):60-66

Zagrobelny M, Bak S, Rasmussen A, Jørgensen B, Naumann C, Møller BL (2004) Cyanogenic glucosides and plant-insect interactions. Phytochemistry 65(3):293-306

Zagrobelny M, Bak S, Møller BL (2008) Cyanogenesis in plants and arthropods. Phytochemistry 69:1457-1468

Publisher's Note Springer Nature remains neutral with regard to jurisdictional claims in published maps and institutional affiliations. 